\title{
The olfactory organ of schilbid catfish Eutropiichthys vacha (Hamilton, 1822): morphological and ultrastructural studies
}

\author{
Saroj Kumar Ghosh@
}

\begin{abstract}
Background: A study of the olfactory organ structure in freshwater catfish, Eutropiichthys vacha, was carried out to explore the cellular constituents by aid of light as well as scanning and transmission electron microscopy.

Results: The paired elongated olfactory organs were situated on the dorsolateral facet of the head in the mold of simple pits. The olfactory organ was made up of a series of leaflets, the lamellae, which embedded into both sideways of slender central raphe, forming a rosette distinguished with sensory and nonsensory areas. The sensory receptor cells were present on sideward surface and linguiform process of olfactory lamella while the rest of the portion of the lamella was lined with nonsensory epithelium. Olfactory cells were characterized by their staining intensity, outline, surface features, and comprehensive morphology in the epithelium. The sensory mucosa was defined by the occurrence of three types of neuron: classic types bearing either cilia or numerous microvilli and third type having rod-shaped architecture. The nonsensory epithelium was composed of mucous cells, labyrinth cells, mast cells, and two types of supporting cells categorized as ciliated or nonciliated. Basal cells lie deep in the olfactory lining, near the central core.
\end{abstract}

Conclusion: The structural components of the olfactory apparatus crucial for olfaction were correlated with the behavioral activities of fish.

Keywords: Bacha fish, Chemoreception, Olfactory epithelium, Histomicroscopy, SEM, TEM

\section{Background}

Smell is a significant sensory mediator to recognize the chemical cues and concerned with variant behaviors of fish. Survival in aquatic surroundings, usually deficient of light but abundant with dissolved substances, teleostei possess well-developed chemical sensors and signaling system (Hara, 1994a). Olfactory and gustatory are the main chemosensory pathways that allow the fish to sustain in an aquatic habitat. Sense of olfaction is typically discriminated as a distance chemical receptor with high sensitivity and selectivity while gustation is basically a connection or close territory sense with limited sensitivity (Hara, 1994b). Olfactory taste and chemical

Correspondence: saroj.fisherylab@gmail.com

Department of Zoology, Bejoy Narayan Mahavidyalaya, Itachuna, Hooghly, West Bengal 712 147, India

\section{Springer Open}

information are detected by the sensory terminals of receptor cells in the olfactory organ which transmit signals directly to the central nervous system by the olfactory tract. The olfactory organ plays an essential role in the lives of fishes such as food finding, predator avoiding, parental caring, migration, propagation, and reproduction (Nikonov et al., 2017). Macroscopic and microscopic features of the olfactory organs association with ecological compatibility are reported in different teleostean fishes (Ghosh, 2019; Hamdani \& Døving, 2007; Kasumyan, 2004; Kim et al., 2016; Malick et al., 2018; Miyasaka et al., 2013; Pashchenko \& Kasumyan, 2015; Sarkar et al., 2014). Wide diversity occurs in the olfactory organs of teleosts due to disparities in their habit and habitats. The bottom of nasal cavity is lined by epithelium which is thrown up into lamellae comprising

(c) The Author(s). 2021 Open Access This article is licensed under a Creative Commons Attribution 4.0 International License, which permits use, sharing, adaptation, distribution and reproduction in any medium or format, as long as you give appropriate credit to the original author(s) and the source, provide a link to the Creative Commons licence, and indicate if changes were made. The images or other third party material in this article are included in the article's Creative Commons licence, unless indicated otherwise in a credit line to the material. If material is not included in the article's Creative Commons licence and your intended use is not permitted by statutory regulation or exceeds the permitted use, you will need to obtain permission directly from the copyright holder. To view a copy of this licence, visit http://creativecommons.org/licenses/by/4.0/. 
a mosaic of numerous receptor cells arranged between other nonreceptor cells that varies somewhat in fishes.

The food fish Eutropiichthys vacha belonging to the family Schilbeidae inhabits the sandy or muddy bottom of river water. They are highly predaceous in nature, feeding preferably on aquatic insects, crustaceans, annelids, and small fishes (Abbas, 2010; Hossain et al., 2015). Fundamental information related to histological characteristics and histochemical nature of various cells lining the olfactory mucosa of schilbid catfish has been reported (Ghosh, 2018a, b; Ghosh \& Das, 2020). However, the observations of tissue organization and minute anatomy of the chemosensory olfactory organ are lacking. The present work is an attempt to specify the structural components of organization and function of the olfactory system in $E$. vacha through histological and electron microscopical analysis.

\section{Methods}

\section{Specimen acquiring}

A total of 106 adult specimens of E. vacha (20.5 to 24.2 $\mathrm{cm}$ in total length) were caught between December 2016 and September 2018 from Bhagirathi-Hooghly river, a tributary channel of river Ganga adjacent Kalyani of West Bengal, India, using cast net and drag net. They were identified following a key to classification of fishes by Misra (2003). Specimens were anesthetized with 3\% urethane (Himedia) and sacrificed. The olfactory organs were dissected out thoroughly from the olfactory pits under stereoscopic binocular microscope (Magnus MS24) and processed for relevant techniques.

\section{Light microscopy}

A total of 60 olfactory tissues were fixed in aqueous Bouin's fluid for about $18 \mathrm{~h}$, washed in $70 \%$ ethanol, dehydrated through graded ethanol solutions, cleared in benzene, and embedded in paraffin wax (Sigma-Aldrich, melting point $56-58^{\circ} \mathrm{C}$ ) for $1 \mathrm{~h}$ and $30 \mathrm{~min}$. Transverse sections of tissue block were cut at 4- $\mu \mathrm{m}$ thickness using a rotary microtome (Weswox MT-1090A Senior). Dewaxed tissue sections were stained with Azan Trichrome (AT) (Heidenhain, 1915), Mallory's Triple (MT) (Mallory, 1936), and Delafield's hematoxylin-eosin (HE) (Fischer et al., 2008) stain. The sections were cleared with xylene and mounted with dibutylphthalate polystyrene xylene (Merck). The stained slides were observed and photographed using a light microscope (Carl Zeiss Primo Star) equipped with a Tucsen 5.0 MP camera at different magnifications.

\section{Scanning electron microscopy}

After being exposed, a total of 12 olfactory rosettes were bathed in a solution containing $2.5 \%$ glutaraldehyde buffered with $0.1 \mathrm{M}$ phosphate buffer ( $\mathrm{pH}$ 7.4) for 15 min. The olfactory rosettes were removed from the olfactory pits and gently washed with $1 \%$ Tween 40 solution (Himedia) to remove the excess mucus and debris from the surface. They were immersed in the same buffer, transferred in $2.5 \%$ glutaraldehyde for $24 \mathrm{~h}$ at $4{ }^{\circ} \mathrm{C}$, and post-fixed in $1 \% 0.1 \mathrm{M}$ phosphate-buffered osmium tetroxide $(\mathrm{pH} \mathrm{7.4)}$ for further $2 \mathrm{~h}$ at room temperature. Samples were then dehydrated in a gradation of acetone, changed with isoamyl acetate, dried by critical point method (Cohen, Marlow, \& Garner, 1968) with liquid $\mathrm{CO}_{2}$, and mounted with glue on aluminum stubs. After being sputter coated (BT-150 Coater, Hind High Vacuum Co. Pvt. Ltd.) with platinum $(15 \mathrm{~nm})$, samples were viewed under a scanning electron microscope (SEM) (Zeiss EVO 18).

\section{Semithin sections and transmission electron microscopy}

Small portions of the olfactory rosette from 12 specimens were fixed in modified Karnovsky's solution (2\% glutaraldehyde and $2.5 \%$ paraformaldehyde in $0.1 \mathrm{M}$ phosphate buffer, $\mathrm{pH} 7.4$ ) for $4 \mathrm{~h}$ at $4{ }^{\circ} \mathrm{C}$ and postfixed in $1 \%$ osmium tetroxide in the same buffer for further $2 \mathrm{~h}$ at room temperature. After thoroughly washing in phosphate buffer, the fixed samples were dehydrated in an ascending series of acetone and embedded in araldite following standard protocols. After resin polymerization, transverse semithin sections were cut at 1- $\mu \mathrm{m}$ thickness with a glass knife using ultracut microtome (Leica EM UC7) and stained with toluidine blue (Bozzola \& Russel, 1992). Stained sections were examined under a light microscopy (LM), and microphotographs were taken under Zeiss Primo Star trinocular microscope.

Ultrathin sections (silver to gold) were obtained and double-stained on copper grids with $1 \%$ aqueous uranyl acetate and lead citrate (Glauert, 1975) and examined using a Tecnai G2 20S-Twin transmission electron microscope (TEM) (FEI, Netherlands).

\section{Results \\ Gross anatomy}

In E. vacha (Fig. 1A), each nasal chamber lies dorsolaterally towards the tip of snout, quite anterior to the eye. The nasal cavity has two external nares, incurrent and excurrent, which are separated by a bridge of skin (Fig. 1B). The anterior inlet is oval in outline and occupies obliquely while the posterior outlet is small in size and sickle shaped. The olfactory apparatus contains olfactory chamber, anterior and posterior nares, olfactory rosette equipped with numerous lamella, olfactory bulb, and olfactory nerve. The olfactory rosette remains buried in the base of the nasal chamber, a depression of ethmoid bone of the skull. The nasal chambers of both sides are separated from each other by the intermediary mesethmoid bone. The olfactory bulbs are spherical and 

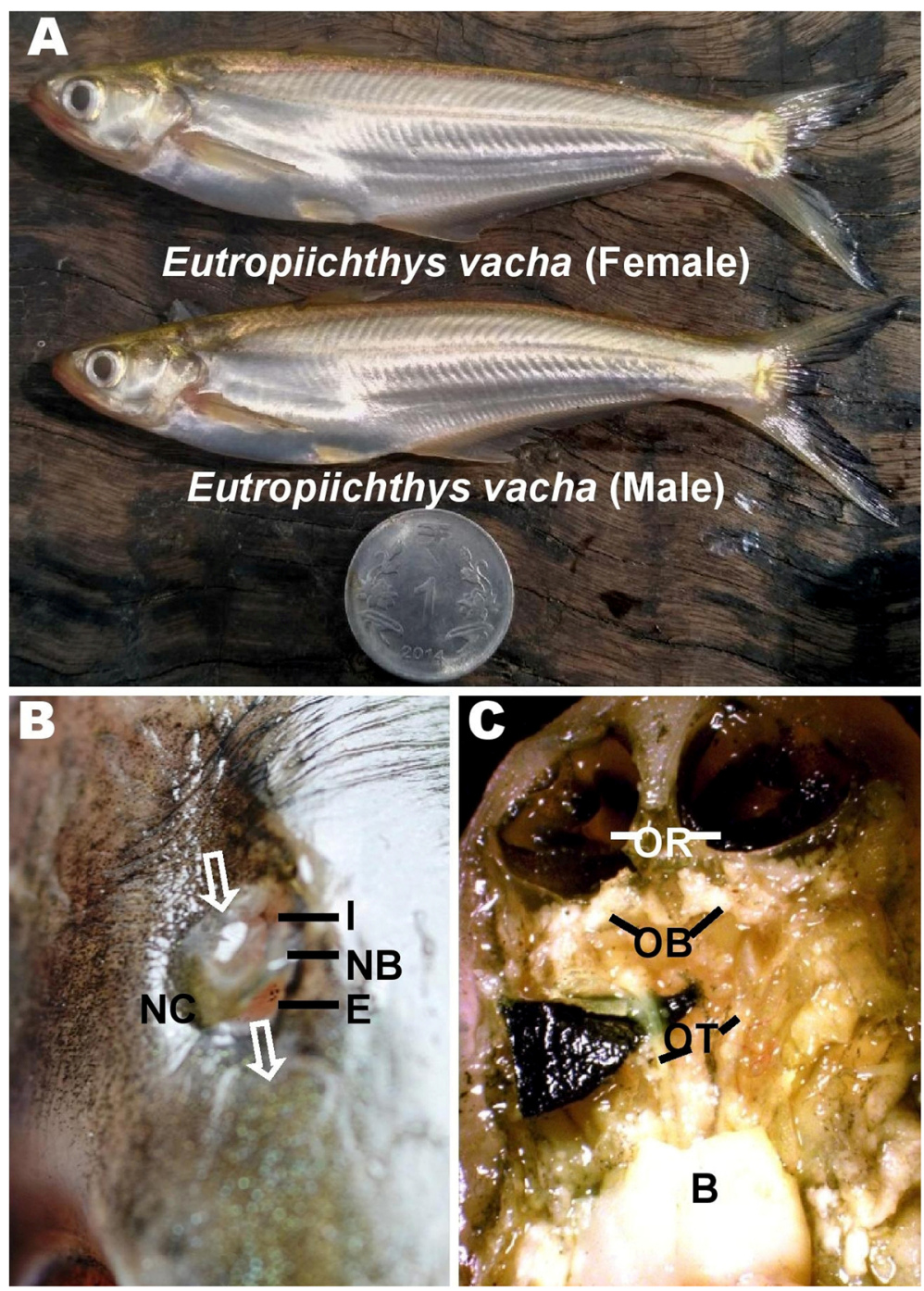

Fig. 1 Photographs showing the anatomical structure of olfactory apparatus in Eutropiichthys vacha. A Female and male E. vacha. B Nasal cavity (NC) exhibits incurrent (I) and excurrent (E) nares distinguished by nasal bridge (NB). Arrows mark pathway of water flow. C Dissected dorsal view of the brain (B) along with olfactory tracts (OT), olfactory bulbs (OB), and olfactory rosettes (OR)

moderately developed. The narrow olfactory tracts are composed of olfactory fibers connecting the olfactory bulbs with basal fore brain (Fig. 1C).

\section{Light microscopy}

Olfactory lamella ramified from raphe shows unequal thickness and is composed of two layers of stratified mucosa encompassing the central core which contains connective tissues with blood vessels and bundle of nerves (Figs. 2A and 3B). The epithelium is isolated from the central core by a prominent basement membrane (Figs. $2 \mathrm{D}$ and $3 \mathrm{~B}, \mathrm{C})$. The olfactory mucosal lining is composed of structurally specific primary receptor cells, secondary receptor cells, microvillous receptor cells, rod receptor cells, and various kinds of nonsensory cells (Fig. 2B). The receptor cells bearing posteriorly placed nuclei are frequently present in the sensory portion of lamella (Fig. 2D). The primary receptor cells are closely arranged in a single row with darkly stained ovaloid nuclei and cylindrical dendrites facing towards the free epithelial margin (Figs. 2D and 3C). The distal edge of the dendrite has a small protrusion, the olfactory knob which has poorly visible apical hairs on the mucosal surface. The receptor cells exhibit bipolar neurons in some regions of mucosa (Fig. 2D). Secondary receptor cells are observed underneath the primary receptor cells, marked by intensely stained elongated nuclei and granular cytoplasm (Fig. 3C). In some parts, the dendrite ends of the secondary receptor cells form synaptic contact with the axons of primary receptor cells. Their axon passes through the basement membrane and stromal sheet, where they assemble to construct an array of 


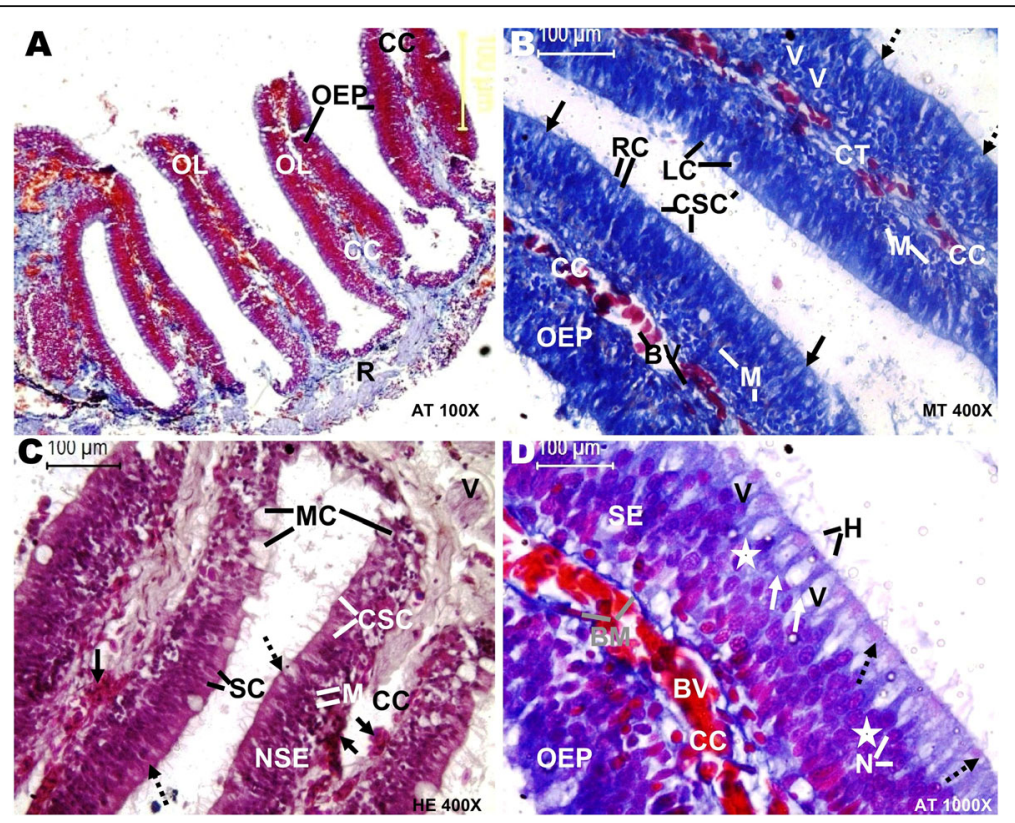

Fig. 2 Histomicroscopy of olfactory organ in E. vacha stained with Azan Trichrome (AT), Mallory's Triple (MT), and Delafield's hematoxylin-eosin (HE) stain. A Olfactory lamellae (OL) connected with raphe (R) exhibit compact olfactory epithelium (OEP) on both side of midline central core (CC). B OEP contains primary receptor cells (RC), rod receptor cells (solid arrows), labyrinth cells (LC), mast cells (M), basal cells (arrow heads), and ciliated (CSC) and nonciliated supporting cells (SC) (broken arrows). CC provided with blood vessels (BV) and connective tissue fibers (CT). C Basal portion of lamella shows nonsensory epithelium (NSE) with secretory mucous cells (MC), labyrinth cells (broken arrows), M, SC, CSC. CC contains BV (solid arrows). Arrow head marks fila olfactoria. D Part of sensory epithelium (SE) shows primary receptor cells (solid arrows) with nuclei (N) and apical hairs $(\mathrm{H})$, rod receptor cell (asterisks), and microvillous cells (broken arrows). Basement membrane (BM) separates OEP from CC which contains cluster of BV. Arrow heads indicate bipolar neuron

olfactory fibers. Microvillous receptor cells are more marginal in the olfactory lining, portrayed with moderately stained round nuclei and flat surface (Figs. 2D and 3C). Rod receptor cells are distinguished by their columnar layout, bearing basally placed spindle-shaped nuclei and wide length dendrite tips towards the mucosal outside.

The nonsensory epithelium is characterized by labyrinth cells, mast cells, mucous cells, and two types of supporting cells: ciliated and without cilia (Figs. $2 \mathrm{~B}$ and $\mathrm{C}$ and $3 \mathrm{~B}$ and $\mathrm{D}$ ). Labyrinth cells are distributed randomly in the exterior border of the mucosa. They are fairly large and globular in appearance having prominent rounded basally or medially placed nuclei. Mononuclear mast cells are ovoid in outline having granulated cytoplasm, scattered in the middle zone of epithelium. Empty mucous cells are irregular in shape containing basally placed nuclei, release their content on the epithelial surface (Fig. 2C). Ciliated supporting cells are almost columnar in pattern with a flat surface sculpted with cilia.The nonciliated supporting cells with basophilic central nuclei are peppered with other olfactory cells forming a mosaic (Figs. 2B, C and 3D). The basal cells appear as stem cells which contain conspicuous large nuclei, lying nearby basement membrane (Figs. 2B, 3B, C).

\section{Scanning electron microscopy}

Each olfactory organ is expressed by an elongated, laterally constricted rosette-like arrangement having a long medial axis, bearing 34-38 radial lamellae organized on each of the linear raphe (Fig. 4A). The lamellae are distensions of raphe and connected onward its ventral margin with the floor of olfactory cup. The lamellae are flat on both sides, intimately arranged parallel to each other in a perpendicular plane and their concave outer edges with linguiform growths at distal ends. They are closely set on the right and left side of the rosette. The extension of lamella differs regarding their layout in rosette. The lamellae of the middle portion of the rosette are broad and diminish in size towards anterior and posterior ends. The lateral covering and linguiform process of lamella contains sensory mucosa while the rest of the lamella is lined with nonsensory mucosa (Fig. 4B). Sensory and nonsensory mucosae are distinguished based on surface characters and cellular constituents.

The discontinuous sensory mucosa has a large number of receptor cells which are differentiated on the basis of free terminals and categorized into ciliated, rod, and microvillous receptor cells (Fig. 4C and D). Ciliated receptor cells bear narrow hillock-like tips emerging from their cell body. The microvillous receptor cells are covered with compressed microvilli like protuberances, 


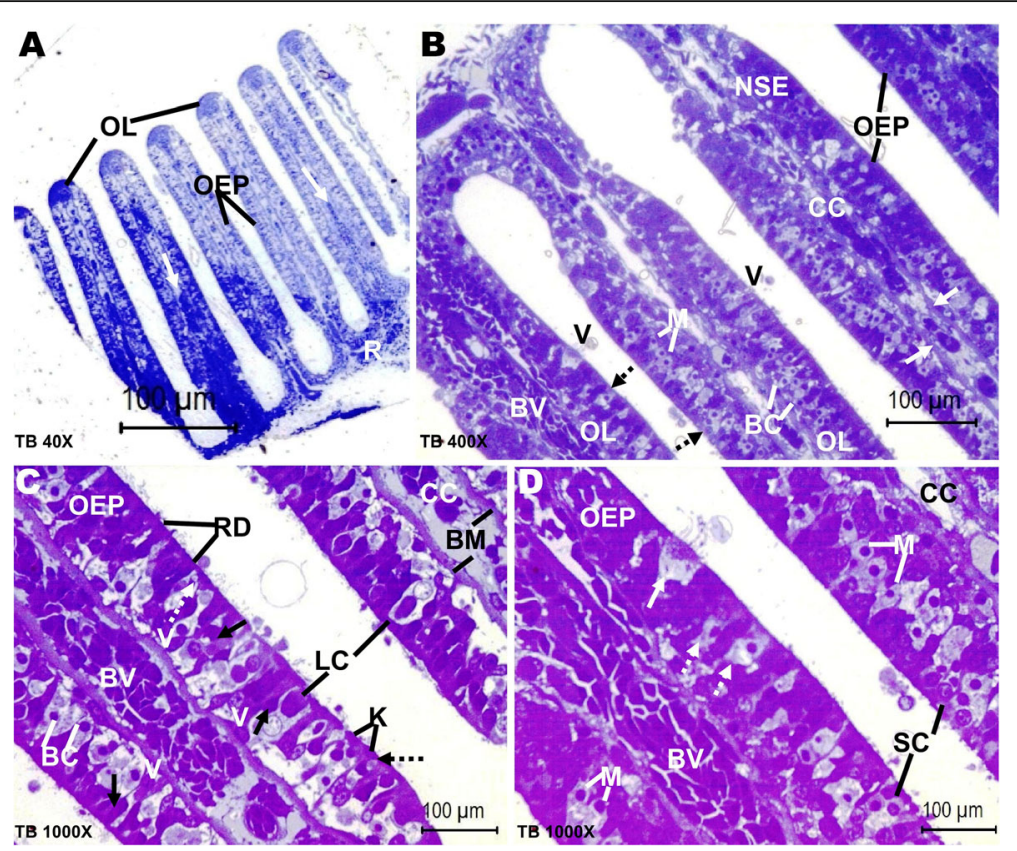

Fig. 3 Photomicrographs of the semithin sections of the olfactory lamella in E. vacha stained with toluidine blue (TB). A Transverse section of olfactory lamella (OL) proliferated from raphe (R) shows olfactory epithelium (OEP) and central core (arrows). B OL shows nonsensory epithelium (NSE) containing ciliated supporting cells (arrow heads), labyrinth cells (broken arrows), mast cells (M), and basal cells (BC). CC supported with blood vessels (BV) segregates from OEP by basement membrane (solid arrows). C Magnified sensory OEP illustrates primary receptor cells (solid arrows) synaptic connection with secondary receptor cells (arrow heads), microvillar cells (broken arrows), and rod cells (RD). Note presence of BV in CC, which is distinguished from OEP by BM. K for olfactory knob (K), BC for basal cells, and LC indicates labyrinth cells. D Higher magnification of nonsensory OEP portrayed with mast cells (M), labyrinth cells (broken arrows), ciliated supporting cell (solid arrow), and nonciliated supporting cells (SC). CC contains BV

giving sculpture surfacing over the mucosa. Rod-shaped receptor cells are observed sporadically, distended as compound tips at the free surface of epithelium. The rod-like structure tapers progressively towards the tip. The sensory region shows hairy appearance due to the occurrence of condensed cilia.

The larger non-sensory epithelia contain stratified epithelial cells with plentiful microfolds and compact assemblage of ciliated supporting cells interposed with secretory mucous cells. Mucus droplets are marked over the parts of free surface. The ciliated nonsensory cells show dense aggregation over the surface of lamella (Fig. $4 \mathrm{E})$. Scattered labyrinth cells having inward folding are detected in between the tuft of receptor cells (Fig. 4C and D). A sharp difference is seen in between the epithelial lining of lamella and raphe. The raphe consists mostly of stratified epithelial cells containing zigzag pattern microridges, and mucous cells randomly dispersed mucous cells (Fig. 4F). Secreted mucin from mucous cells is deposited over the stratified epithelial cells. No cilia are observed on the midline raphe.

\section{Transmission electron microscopy}

The sensory olfactory mucosa containing 3 morphotypes of receptor neurons are differentiated from other olfactory cells by their cell soma, characteristic length, and architecture of dendritic processes. The sensory neurons are confined at the apical edge of the mucosa, furnished with ciliated knob, without cilia but with short microvillar or rod-forming tips (Fig. 5A). The ciliated receptor cell is characterized with apical dendrite having many microtubules that arise from basal body of the cell (Fig. 5B). The nucleus lies deep in the cell, and cytoplasm is crowded with mitochondria, electron dense granules, and more than one pair of centrioles. A tight junctional complex is observed between adjoining cells. Microvillous receptor cell without cilia is embossed with tuft of minute microvilli. They are deeply infolded in apical portion and have a number of adherent electron opaque vesicles (Fig. 5B and C). Specialized rod cells are seen infrequently in the epithelium and have a continuous tapering spoke-like axonal process above the epithelial surface. The axonal process has longitudinally oriented microtubules along the axis. Aggregations of free ribosomes, centrioles, and electron-dense vesicles are noted. In the dendrite of ciliated and rod receptor cells, the microtubules are aligned in the $9+2$ order in transverse section (Fig. 5D).

The basal cells containing lobular nuclei are intermingled in the deeper layer of olfactory mucosa close to 

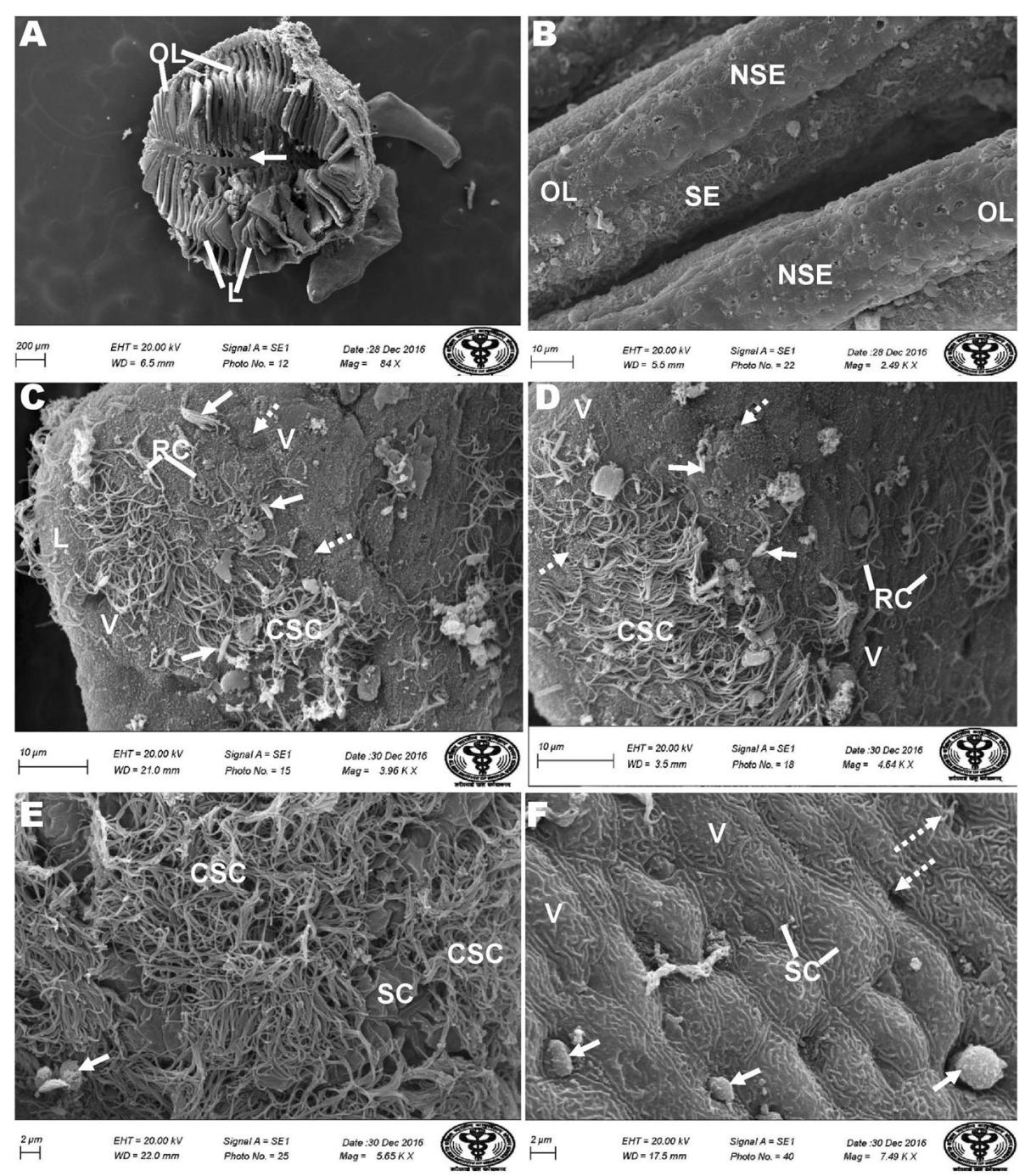

Fig. 4 Photomicrographs of the topological view of olfactory epithelia of E. vacha by scanning electron microscopy (SEM). A Dorsal view of gross olfactory rosette furnishes olfactory lamellae (OL) with linguiform processes (L) emitted from raphe (arrow). B Alignment of sensory (SE) and nonsensory (NSE) epithelium on OL. C Sensory islet of linguiform process (L) shows dendrite tips of ciliated receptor cells (RC), rod cells (RD) (solid arrows), and microvillous cells (arrow heads). Note the presence of ciliated supporting cells (CSC) and labyrinth cells (LC) (broken arrows). D Lateral surface of lamella shows sensory epithelium with RC, rod cells (solid arrows), and microvillous cells (arrow heads), and nonsensory epithelium contains CSC and labyrinth cells (broken arrows). E Surface of nonsensory mucosa illustrates dense aggregation of ciliated supporting cells (CSC) and nonciliated supporting cells (SC). Arrow marks mucin masses. F Close up view of raphe exhibits SC with conspicuous microridges (arrow heads) and elevated mucous cell (broken arrows). Note the presence mucin balls (solid arrows) over SC

basement membrane (Fig. 5E). The nucleus has dense heterochromatin, scattered everywhere inside. Cytoplasm contains conspicuous rough endoplasmic reticulum, mitochondria, well-developed Golgi complexes, and secretory vesicle (Fig. 5F). Mast cells with opaque nuclei, surrounded by cisterns of rough endoplasmic reticulum are distributed in the middle of the epithelium (Fig. 5E). A large number of mitochondria are present in the cytoplasm (Fig. 6C). Mucous cells are circumscribed in the periphery of nonsensory mucosa and rich in secretory vesicles and packed with granules (Figs. 5E, 6A, B, E). Due to accumulation of copious secretory vesicles, nucleuses together with other organelles are basally located (Fig. 6B). Labyrinth cells are bulbous in contour, with profuse filamentous mitochondria and homogenous fine granules (Fig. $6 \mathrm{~A}$ and F). The nonciliated supporting cells are columnar with basally located nuclei and mitochondria (Fig. $6 \mathrm{~A}, \mathrm{C}$, and D). The ciliated supporting cells are disbursed on the mucosal border, having extended flat apical surface containing a number of cilia. These are common motile cilia showing predominant 9 peripheral plus 2 central microtubule patterns (Fig. 6D). Striated rootlets continuing from basal bodies are found in the cell apex which gives rise 


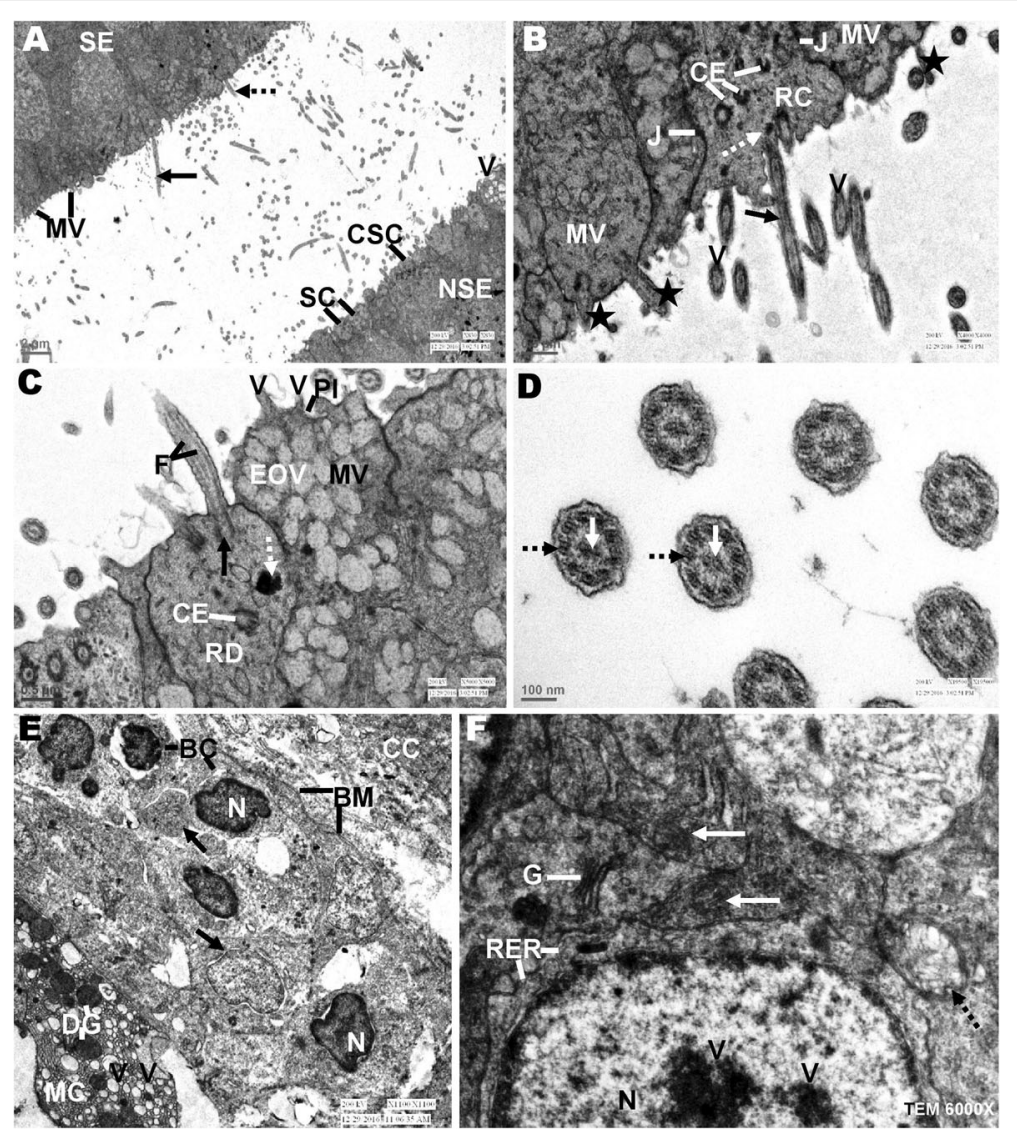

Fig. 5 Photomicrographs of the olfactory lining of E. vacha by transmission electron microscopy (TEM). A Sensory epithelium (SE) contains ciliated receptor cell (solid arrow), microvillous receptor cells (MV), and rod cell (broken arrow) while nonsensory epithelium (NSE) with nonciliated supporting cell (SC), ciliated supporting cell (CSC), and mucous cell (arrow head). B Sensory part shows MV with minute microvilli (asterisks), ciliated RC with dendrite process of (solid arrow) arises from basal body (broken arrow) and centrioles (CE). RC exhibits junctional complex (J) with neighboring cells. Arrow heads indicate cross section of cilia. C Sensory epithelium illustrates MV with electron opaque vesicles (EOV), minute microvilli (arrow heads), and pinocytotic invagination (PI) on apical surface. Rod cell (RD) exhibits spike-like projection having parallel arranged microfilaments (F) emerged from basal body (solid arrow), centriole (broken arrow), and electron-dense vesicle (broken arrow). D Transverse section of cilia shows 9 pairs of peripheral microtubules (broken arrows) and 2 central ones (solid arrows). E Nonsensory mucosa shows basal cells (BC) with nuclei (N), mast cells (solid arrows), and mucous cell (MC) with dense granules (DG) and vacuoles (arrow heads). Note the basement membrane (BM) in between mucosa and central core (CC). F Nucleus (N) of basal cells having fragmented heterochromatin (arrow heads) surrounded by rough endoplasmic reticulum (RER). Note the presence of mitochondria (solid arrows) and Golgi apparatus (G) and secretory vesicle (broken arrow) adjacent to nucleus

to many cilia (Fig. 6C). These have mitochondria, vacuoles, and moderate electron lucent membrane obligated vesicles in the apical cytoplasm (Fig. 6B and D). The central raphe mainly consists of supporting cells having irregular-shaped nuclei containing fragmented heterochromatin and a few secretory vesicles. Cytoplasm holds scanty rough endoplasmic reticulum, free ribosomes, and multitude of electron-blurred particles (Fig. 6F).

\section{Discussion}

The structural specialization and cellular composition of olfactory organ is related to the ecological behavior of fish. Sense of smell in fish is commonly concerned with the water ventilation by sniffing process (Nevitt, 1991). The water enters through the anterior inlet and comes out of the posterior outlet after bathing the olfactory mucosa. Relevant ventilation of the nasal chamber is requisite for carrying the chemical cues over the olfactory lining for acquiring the chemical information of the aquatic environment (Belanger et al., 2003). Nasal bridge is necessary for circulation of water through anterior nare and comes out of the posterior nare. E. vacha have a good sense of olfaction and can judge the chemical stimuli by multilamellar olfactory organ linked to the olfactory lobes of the forebrain by cranial nerves I.

The occurrence of greater number of olfactory lamella in E. vacha is due to their bottom-dwelling habit and well-developed olfactory acuity. The present work confirms that the olfactory rosette is an elongated structure that belongs to the 3rd group of nose fishes (Teichmann, 


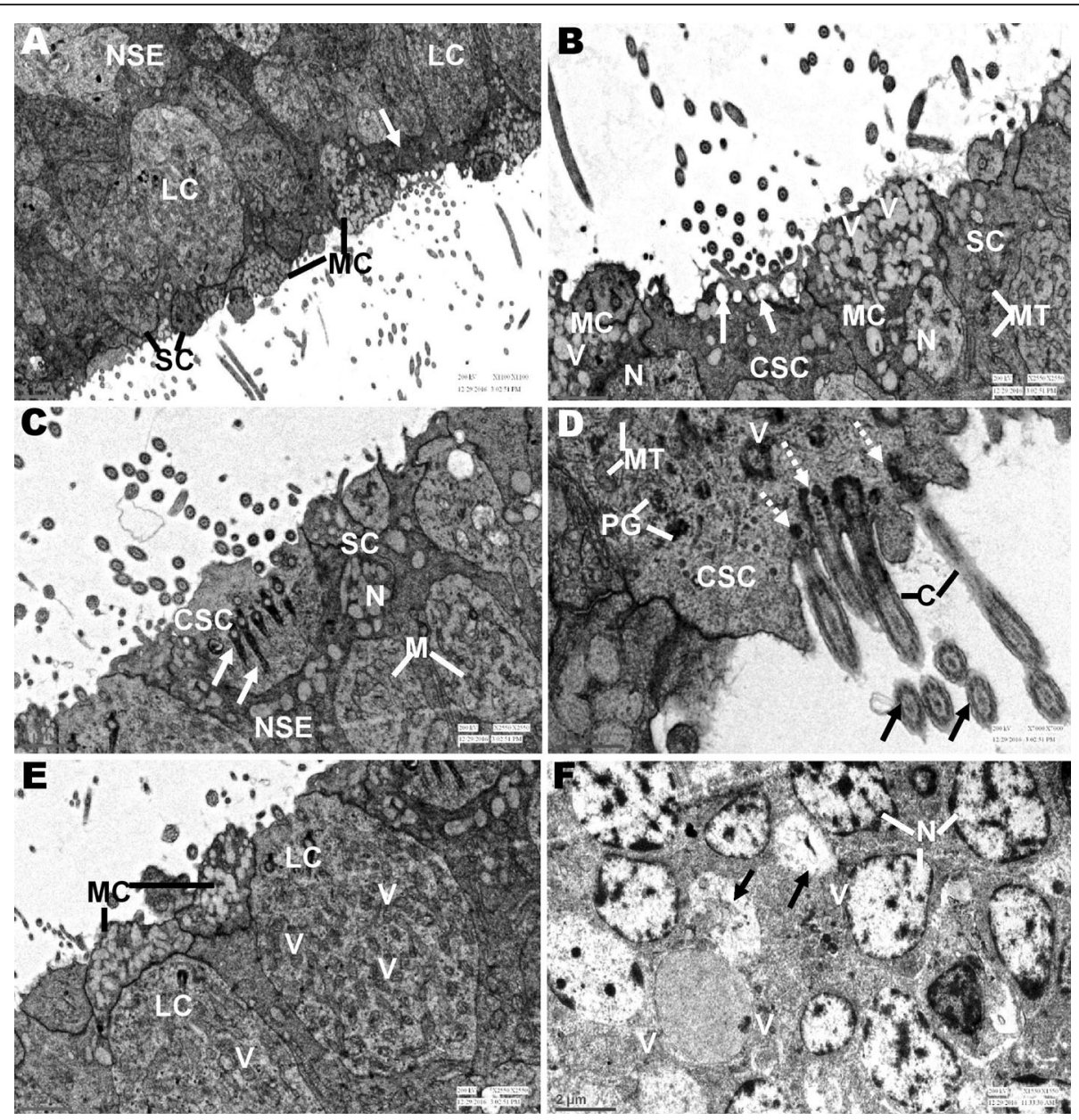

Fig. 6 Photomicrographs of the olfactory organ of E. vacha by transmission electron microscopy (TEM). A Nonsensory epithelium (NSE) lined with nonciliated supporting cells (SC), ciliated supporting cell (CSC) (solid arrow), labyrinth cells (LC), and mucous cell (MC). B Mucosa shows CSC with vacuoles (solid arrows), SC with mitochondria (MT), and MC containing basally placed nuclei (N) and secretory vesicles (arrow heads). C NSE typified with CSC having striated rootlets (solid arrows), mast cells (M), and SC containing nuclei (N). D Close up view of CSC shows plenty of kinocilia (C) with compact microtubules that arise from basal bodies (broken arrows), centriole (arrow head), mitochondria (MT), and pale granules (PG). Solid arrows mark classic arrangement of microtubules. E NSE shows labyrinth cells (LC) compacted with mitochondria (arrows) and vacuolated mucous cells (MC). F Raphe contains supporting cell nuclei (N) with dispersed heterochromatin. Note rough endoplasmic reticulum (arrow heads) and vesicles (solid arrows) adjacent to nuclei

1954) which acquire greater olfactory area in comparison to retinal sphere. In olfactory rosette, lamellae orient uniformly from both side of midline raphe, classified by Yamamoto (1982) Type-H, i.e., double-sided comb-like appearance along a raphe. Functional ability of the chemosensory olfactory organ in a teleost increases in direct proportion to the higher number of lamellae and its epithelial lining (Ojha \& Kapoor, 1973). The lamellae bear specialized linguiform processes which forward the movement of water over the olfactory rosette. The linguiform processes slow down the water current over the lamella and facilitate better interaction of odorant particles with chemosensory cells of sensory islets. Dispersal of sensory and nonsensory mucosa on the olfactory lamellae shows enormous diversity in fish belonging to particular taxonomic levels, and varying habits are necessarily an adaptive aspect (Yamamoto, 1982).

The apical part of the sensory mucosa is lined with receptor cells, responsible for a specific reaction with ligands (Kuciel et al., 2011). The sensory neurons mediate behavior of the fish. The receptor cells are of three types: characterized with ciliated edges or with microvillar tips or rod-shaped endings which are adept to respond and recognize the chemical stimuli in the surroundings ecosystem. The ciliated receptor cells correspond to type I cell of Yamamoto \& Ueda (1978), though microvillous receptor cells to type II cells of Muller \& Marc (1984), and rod receptor cells of those type IV cells of Ichikawa Ueda (1977). Each neuron carries unequivocal chemical stimuli that bring out distinctive behavior in response to 
olfactory cues associated with crucial life processes of fish (Hamdani \& Døving, 2007). The distal ends of ciliated receptor cells have olfactory knob supported with sensory hairs that are recognized as the locus of receptor sites for odouriferous particles. Zippel et al., (1997) advocated that ciliated neurons perform counter to amino acids while the microvillar neurons mediate comeback to pheromones. The microvillous receptor cells recognize and communicate with pheromone, which is a momentous adventure of breeding in Labeo rohita (Bhute \& Baile, 2007). Datta \& Bandopadhyay (1997) reported that rod cell is not a usual subtype, the forming of rod probably due to fusion of cilia of ciliated region. Hernádi (1993) reported that the presence of the rod cell is due to habitat of a new physiological climate. Existence of rod receptor cells reveals the marking of aged ciliated receptor cells (Yamamoto, 1982). The occurrence of microtubules is probably responsible for maintaining the shape of the dendrite process and channelizing different transport materials to the particular site (Datta \& Bandopadhyay, 1997). Theisen (1972) reported microtubules in dendrite of receptor neurons presumably the main role for recognition of chemical cues. Group of mitochondria in the receptor cell suggests that they are providing the needed energy for the beating of cilia. The attentive aspect of the present work is the detection of secondary neurons in addition to primary neurons and the presence of synaptic connections between these two types of neurons in the olfactory epithelium. The axons of the secondary neurons may extend into the central core of the lamellae, suggesting that the impulses received by the dendrite of primary receptor cells ultimately send impulses to the central core and carried over into the brain finally. Ojha and Kapoor (1973) also found secondary neurons in the olfactory epithelium of Labeo rohita.

The nonsensory epithelium is comprised of supporting cells, helping in mechanical dissociation and to secrete substances onto the mucosa of the olfactory lamella (Hara, 1994b). The ciliary process of nonsensory cells generates a feeble current that closed the lamellae and perform as guides facilitating dissolved chemicals to contact tips of sensory neurons bearing receptor sites (Hara, 2000). The supporting cells embossed with kinocilia have to propel water and/or mucus over the lamella. Kinocilia have dynein arms that furnish their motility (Zeiske et al., 1992). The labyrinth cells cell type is similar to chloride cells which probably are involved in electrolyte transport in fish gills and pseudobranch (Bertmar, 1972). Mast cells in the olfactory mucosa are believed to play an important role in reproduction of Labeo rohita (Bhute \& Baile, 2007) and Baltic trout (Bertmer, 1982). They can change metabolic activity of receptors and thereby the sensitivity of olfactory epithelium. The rough endoplasmic reticulum and mitochondria also suggest its functional state. The basal cells are conceited to be the progenitor cells of the receptor and supporting cells (Zeiske et al., 1992). The occurrence of basal cells buried in the epithelium abets to sustain the mucosa during normal cell turnover or necrobiosis. Mucous cells secrete mucin to shield the mucosa from mechanical injury and help in binding the microscopic junk to keep the sensory receptor accessible for new odorants. The deposited mucus from the mucous cells possibly assists for coalesce microscopic remains and by that retains the receptor neurons get for new stimuli. Zeni \& Stagni (2002) opined that the mucus covering the olfactory lamellae constitutes an important medium in which the odorants are diffused like that of other olfactory systems of vertebrates.

\section{Conclusion}

E. vacha acquire considerably developed macrosmatic olfactory organs specialized with distinctive sensory cells in adaptation to the ecological habitat in which they live. Predominance of precise ciliated, microvillar, or rod receptor cells in the sensory mucosa has differentiated chemoattraction capability and is accomplished to judge the chemical characteristics in the surroundings. For better understanding of the chemosensory system in affinity to necessary life processes of the organism, more experimental researches are to be advocated.

\section{Abbreviations \\ I: Incurrent nare; E: Excurrent nare; NB: Nasal bridge; OR: Olfactory rosette; OB: Olfactory bulb; OT: Olfactory tract; B: Brain; OL: Olfactory lamella; R: Raphe; OEP: Olfactory epithelium; SE: Sensory epithelium; NSE: Nonsensory epithelium; CC: Central core; RC: Ciliated receptor cells; RD: Rod receptor cells; MV: Microvillous receptor cells; H: Sensory hair; K: Knob; LC: Labyrinth cells; CSC: Ciliated supporting cells; SC: Nonciliated supporting cells; M: Mast cells; MC: Mucous cells; BC: Basal cells; N: Nuclei; CE: Centriole; J: Junctional complex; EOV: Electron opaque vesicles; PI: Pinocytotic invagination; F: Microfilaments; DG: Dense granules; PG: Pale granules; G: Golgi complex; RER: Rough endoplasmic reticulum; MT: Mitochondria; C: Cilia; BM: Basement membrane; CT: Connective tissues; BV: Blood vessels}

\section{Acknowledgements}

The author feels delightful to the authority of Sophisticated Analytical Instrumentation Facility (SAIF), All India Institute of Medical Sciences (AllMS), New Delhi-110029, India, for technical help with the electron microscopy.

\section{Author's contributions}

SKG designed and performed this research work. The author read and approved the final manuscript.

\section{Funding}

The research work was financially supported by the grants University Grants Commission (UGC), Eastern Regional Office, Kolkata-700098, West Bengal [No.: F.PSW-016/15-16 (ERO) ID No. WB1-014 Dated 15-Nov-16].

Availability of data and materials Not applicable. 


\section{Ethics approval and consent to participate}

Not applicable. In India, native researcher does not need permission to procure animals except if the geographical area of acquiring is in wildlifeprotected area (The Gazette of India, REGD. NO. D. L.-33004/99; Section-17),

\section{Consent for publication}

Not applicable.

\section{Competing interests}

Author declares no competing interest regarding the publication of this manuscript.

Received: 26 May 2020 Accepted: 15 December 2020

Published online: 07 January 2021

\section{References}

Abbas, A. (2010). Food and feeding habits of freshwater catfish, Eutropiichthys vacha (Bleeker). Indian Journal of Scientific Research, 1(2), 83-86.

Belanger, R. M., Smith, C. M., Corkum, L. D., \& Zielinski, B. S. (2003). Morphology and histochemistry of the peripheral olfactory organ of the round goby, Neogobius melanostomus (Teleostei; Gobiidae). Journal of Morphology, 257(1), 62-71. https://doi.org/10.1002/jmor.10106.

Bertmar, G. (1972). Labyrinth cells, a new cell type in vertebrate olfactory organs. Zeitschrift für Zellforschung und Mikroskopische Anatomie, 132, 245-256. https://doi.org/10.1007/BF00307014.

Bertmer, G. (1982). Structure and function of the olfactory mucosa of migrating Baltic trout under environmental stresses, with special reference to water pollution. In T. J. Hara (Ed.), Fish chemoreception, (pp. 395-422). Amsterdam: Elsevier.

Bhute, Y. V., \& Baile, V. V. (2007). Organization of the olfactory system of the Indian Major Carp Labeo rohita (Hamilton): A scanning and transmission electron microscopic study. Journal of Evolutionary Biochemistry and Physiology, 43(3), 342-349. https://doi.org/10.1134/5002209300703009X.

Bozzola, J. J., \& Russel, L. D. (1992). Electron microscopy, principles and techniques for biologists. Burlington: Jones \& Bartlett Learning.

Cohen, A., Marlow, D., \& Garner, G. (1968). A rapid critical point method using fluorocarbon ("freons") as intermediate and transitional fluids. Journal of Microscopy, 7, 331-342.

Datta, N. C., \& Bandopadhyay, S. (1997). Ultrastructure of cell types of the olfactory epithelium in a catfish, Heteropneustes fossilis (Bloch). Journal of Bioscience, 22, 233-245. https://doi.org/10.1007/BF02704736.

Fischer, A. H., Jacobson, K. A., Rose, J., \& Zeller, R. (2008). Hematoxylin and eosin staining of tissue and cell sections. Cold Spring Harbor Protocol, 3, 1-3. https://doi.org/10.1101/pdb.prot4986.

Ghosh, S. K. (2018a). Cellular organization of the olfactory epithelium during growth, maturation, spawning and post-spawning phases of freshwater catfish, Eutropiichthys vacha (Hamilton, 1822) (Teleostei: Siluriformes). Iranian Journal of Ichthyology, 5(2), 126-138. https://doi.org/10.22034/iji.v5i2.278.

Ghosh, S. K. (2018b). Anatomical and histological studies on the olfactory organ of riverine catfish, Eutropiichthys vacha (Hamilton, 1822). Asian Journal of Animal and Veterinary Advances, 13(3), 245-252. https://doi.org/10.3923/ajava. 2018.245.252.

Ghosh, S. K. (2019). Histology and surface morphology of the olfactory epithelium in freshwater teleost, Clupisoma garua (Hamilton, 1822). Fisheries and Aquatic Life, 27(3), 122-129. https://doi.org/10.2478/aopf-2019-0014.

Ghosh, S. K., \& Das, S. (2020). The olfactory mucosa of river catfish, Eutropiichthys vacha (Hamilton, 1822): A histochemical study. International Journal of Aquatic Biology, 8(1), 50-55. https://doi.org/10.22034/ijab.v8i1.773.

Glauert, A. M. (1975). Fixation, dehydration and embedding of biological specimens. New York: Elsevier and North-Holland.

Hamdani, H., \& Døving, K. B. (2007). The functional organization of the fish olfactory system. Progress in Neurobiology, 82(2), 80-86. https://doi.org/10. 1016/j.pneurobio.2007.02.007.

Hara, T. J. (1994a). Olfaction and gustation in fish: An overview. Acta Physiologica Scandinavica, 152(2), 207-217. https://doi.org/10.1111/j.1748-1716.1994. tb09800.x.

Hara, T. J. (1994b). The diversity of chemical stimulation in fish olfaction and gestation. Reviews in Fish Biology and Fisheries, 4, 1-35. https://doi.org/10. 1007/BF00043259.

Hara, T. J. (2000). Chemoreception. In G. K. Ostrander (Ed.), The laboratory fish, (pp. 471-479). London: Academic press.
Heidenhain, M. (1915). Über die Mallorysche Bindegewebsfärbung mit Karmin und Azokarmin als Vorfarben. Zeitschrift für wissenschaftliche Mikroskopie und mikroskopische Technik, 32, 361-372.

Hernádi, L. (1993). Fine structural characterization of the olfactory epithelium and its response to divalent cations $\mathrm{Cd}^{2+}$ in the fish Alburnus alburnus (Teleostei, Cyprinidae): A scanning and transmission electron microscopic study. Neurobiology, 1(1), 11-31.

Hossain, M. Y., Hossain, M. A., Ahmed, Z. F., Islam, R., Hossen, M. A., Rahman, M. M. , \& Ohtomi, J. (2015). Threatened fishes of the world: Eutropiichthys vacha (Hamilton, 1822) (Siluriformes: Schilbeidae). Croatian Journal of Fisheries, 73(2), 80-82. https://doi.org/10.14798/73.2.798.

Ichikawa, M., \& Ueda, K. (1977). Fine structure of the olfactory epithelium in the goldfish, Carassius auratus. A study of retrograde degeneration. Cell and Tissue Research, 183(4), 445-455. https://doi.org/10.1007/bf00225659.

Kasumyan, A. O. (2004). The olfactory system in fish: Structure, function, and role in behavior. Journal of Ichthyology, 44(S2), 180-223.

Kim, T. K., Kim, H. S., \& Park, J. Y. (2016). The anatomy and histology of the olfactory organ in the Korean sand goby Favonigobius gymnauchen (Pisces, Gobiidae). Korean Journal of Ichthyology, 28(1), 28-34.

Kuciel, M., Żuwala, K., \& Jakubowski, M. (2011). A new type of fish olfactory organ structure in Periophthalmus barbarous (Oxudercinae). Acta Zoologica (Stockholm), 92(3), 276-280. https://doi.org/10.1111/j.1463-6395.2010.00459.x.

Malick, C., Chatterjee, S. K., Bhattacharya, S., Suresh, V. R., Kundu, R., \& Saikia, S. K. (2018). Structural organization of the olfactory organ in an amphihaline migratory fish Hilsa, Tenualosa ilisha. Microscopy Research and Technique, 81(10), 1122-1131. https://doi.org/10.1002/jemt.23095.

Mallory, F. B. (1936). The aniline blue collagen stain. Stain Technology, 11(3), 101102. https://doi.org/10.3109/10520293609110505.

Misra, K. S. (2003). An aid to the identification of the common commercial fishes of India and Pakistan. Delhi: Narendra Publishing House.

Miyasaka, N., Wanner, A. A., Li, J., Mack-Bucher, J., Genoud, C., Yoshihara, Y., \& Friedrich, R. W. (2013). Functional development of the olfactory system in zebrafish. Mechanisms of Development, 130(6-8), 336-346. https://doi.org/10. 1016/j.mod.2012.09.001.

Muller, J. F., \& Marc, R. E. (1984). Three distinct morphological classes of receptors in fish olfactory organs. Journal of Comparative Neurology, 222(4), 482-495. https://doi.org/10.1002/cne.902220403.

Nevitt, G. A. (1991). Do fish sniff? A new mechanism of olfactory sampling in pleuronectid flounders. Journal of Experimental Biology, 157, 1-18.

Nikonov, A. A., Butler, J. M., Field, K. E., Caprio, J., \& Maruska, K. P. (2017). Reproductive and metabolic state differences in olfactory responses to amino acids in a mouth brooding African cichlid fish. Journal of Experimental Biology, 220, 2980-2992. https://doi.org/10.1242/jeb.157925.

Ojha, P. P., \& Kapoor, A. S. (1973). Structure and function of the olfactory apparatus in the freshwater carp, Labeo rohita (Ham. Buch.). Journal of Morphology, 140(1), 77-85. https://doi.org/10.1002/jmor.1051400107.

Pashchenko, N. I., \& Kasumyan, A. O. (2015). Scanning electron microscopy of development of the olfactory organ in ontogeny of grass carp Ctenopharyngodon idella. Journal of Ichthyology, 55(6), 880-899. https://doi. org/10.1134/S0032945215060132.

Sarkar, S. K., Biswas, S., Datta, N. C., \& De, S. K. (2014). Postnatal development of olfactory apparatus in Labeo rohita (Hamilton, 1822). International Journal of Science and Nature, 5(1), 480-485.

Teichmann, H. (1954). Vergleichende Untersuchungen an der Nase der Fische. Zeitschrift für Morphologie und Ökologie der Tiere, 43, 171-212. https://doi.org/ 10.1007/BF00412849.

Theisen, B. (1972). Ultrastructure of the olfactory epithelium in the Australian lungfish, Neoceratodus forsteri. Acta Zoologica Stockholm, 53(2), 205-218. https://doi.org/10.1111/j.1463-6395.1972.tb00588.x.

Yamamoto, M. (1982). Comparative morphology of the peripheral olfactory organ in teleosts. In T. J. Hara (Ed.), Chemoreception in fishes, (pp. 35-59). Amsterdam: Elsevier.

Yamamoto, M., \& Ueda, K. (1978). Comparative morphology of fish olfactory epithelium-III. Cypriniformes. Bulletin of the Japanese Society of Scientific Fisheries, 44(11), 1201-1206. https://doi.org/10.2331/suisan.44.1201.

Zeiske, E., Theisen, B., \& Breucker, H. (1992). Structure, development and evolutionary aspects of the peripheral olfactory system. In T. J. Hara (Ed.), Fish chemoreception, (pp. 13-39). London: Chapmann and Hall.

Zeni, C., \& Stagni, A. (2002). Changes in the olfactory mucosa of the black bullhead Ictalurus melas induced by exposure to sublethal concentrations of 
sodium dodecylbenzene sulphonate. Diseases of Aquatic Organisms, 51(1), 37-47. https://doi.org/10.3354/dao051037.

Zippel, H. P., Sorensen, P. W., \& Hansen, A. (1997). High correlation between microvillous olfactory receptor cell abundance and sensitivity to pheromones

in olfactory nerve-sectioned goldfish. Journal of Comparative Physiology, 180,

39-52. https://doi.org/10.1007/s003590050025.

\section{Publisher's Note}

Springer Nature remains neutral with regard to jurisdictional claims in published maps and institutional affiliations.

\section{Submit your manuscript to a SpringerOpen ${ }^{\mathcal{O}}$} journal and benefit from:

- Convenient online submission

- Rigorous peer review

- Open access: articles freely available online

- High visibility within the field

- Retaining the copyright to your article

Submit your next manuscript at $\boldsymbol{\nabla}$ springeropen.com 